\title{
Journal of Soils and Sediments: the first 20 years
}

\section{Philip N. Owens ${ }^{1} \cdot$ Zhihong Xu $^{2}$}

Published online: 18 January 2020

(C) Springer-Verlag GmbH Germany, part of Springer Nature 2020

The year 2020 marks the 20th anniversary of Journal of Soils and Sediments (JSS). Since the first issue of JSS in March 2001, the journal has developed into one of the largest (in terms of the number of papers published) and most respected (as indicated by its journal impact factor) journals in its subject area. Originally, the journal was published by Ecomed but since 2008 has been published by Springer, and now Springer-Nature. This development has greatly helped the journal by increasing its profile and enabling it to expand from four issues a year to 12 issues in recent years. Over the last 20 years, the number of manuscripts submitted to the journal and the number of papers published have steadily increased (Fig. 1). Thus, Volume 1 published 33 citable articles in 2001, which compares to about 370 citable articles published in Volume 19 in 2019.

In 2001, the founding Editors-in-Chief (EiCs) of the journal were Thomas Knacker (Germany), Werner Kördel (Germany), and Willie Peijnenburg (The Netherlands) and the two founding co-editors were Turiough Guerin (Australia) and Jörg Matschullat (Germany). Eric de Deckere (Belgium) and Winfried Blum (Austria) were later added to this list. The journal was established, in part, because of a recognition that soils and sediments had to date been treated as individual environmental compartments, and there was a lack of journals - and thus publications - that looked at the link between the two. Such a link was required with new

Philip N. Owens

Philip.owens@unbc.ca

Zhihong Xu

zhihong.xu@griffith.edu.au

1 Environmental Science Program and Quesnel River Research Centre, University of Northern British Columbia, 3333 University Way, Prince George, British Columbia V2N 4Z9, Canada

2 Environmental Futures Research Institute and School of Environment and Science, Griffith University, 170 Kessels Road, Nathan, Brisbane, QLD 4111, Australia policies and legislation that considered environmental issues at larger spatial scales, such as landscapes and drainage basins. Thus, in the European Union (EU), for example, the Water Framework Directive (WFD) was a major driver for the need to consider the interaction between soils, sediments, water, and chemicals and their associated impacts on water quality and aquatic ecosystems. However, the WFD was severely lacking in the recognition of the role of sediments (Förstner 2002). This, in part, led to the establishment of the EU-funded Sediment Research Network (SedNet), and JSS was the "associated journal" of SedNet. In the early years of the journal, there was considerable interaction between SedNet and JSS including numerous editorials, commentaries, and research articles (e.g., Brils 2001, 2002; Brils and de Deckere 2003). Although there was a strong EU connection with JSS, the aim was also to establish the international standing of the journal through the composition of the editorial board and also by being a "cooperating journal" with the International Union of Soil Sciences (IUSS) (Blum 2002).

In late 2005, the existing EiCs were replaced by Ulrich Förstner (Germany; EiC of Sediments), Wim Salomons (The Netherlands; EiC of Intercompartment), and Zhihong $\mathrm{Xu}$ (Australia; EiC of Soils). These EiCs further strengthened the academic reputation of the journal and increased its international profile. The journal received its first impact factor in 2007; a future editorial will discuss the history of the journal's impact factor values. Ulrich and Wim stepped-down as EiCs at the end of 2010, and in 2011 Phil Owens (Canada) took over as the EiC of Sediments (see Xu and Owens 2010, 2011). Thus, 2020 marks Phil's 10th year and Zhihong's 15th year as co-EiCs of JSS. 2020 also marks a switch in the editorial manager of JSS from Moira Ledger-who performed this position from Landsberg, Germany - to Springer-Nature's offices in New York. Everyone who has been involved with JSS during Moira's tenure as managing editor-including authors, reviewers, and the editorial board - would agree that Moira is one of the reasons for the journal's success. Her passion, hard work, and friendly attitude will be sorely missed, especially by the EiCs. 


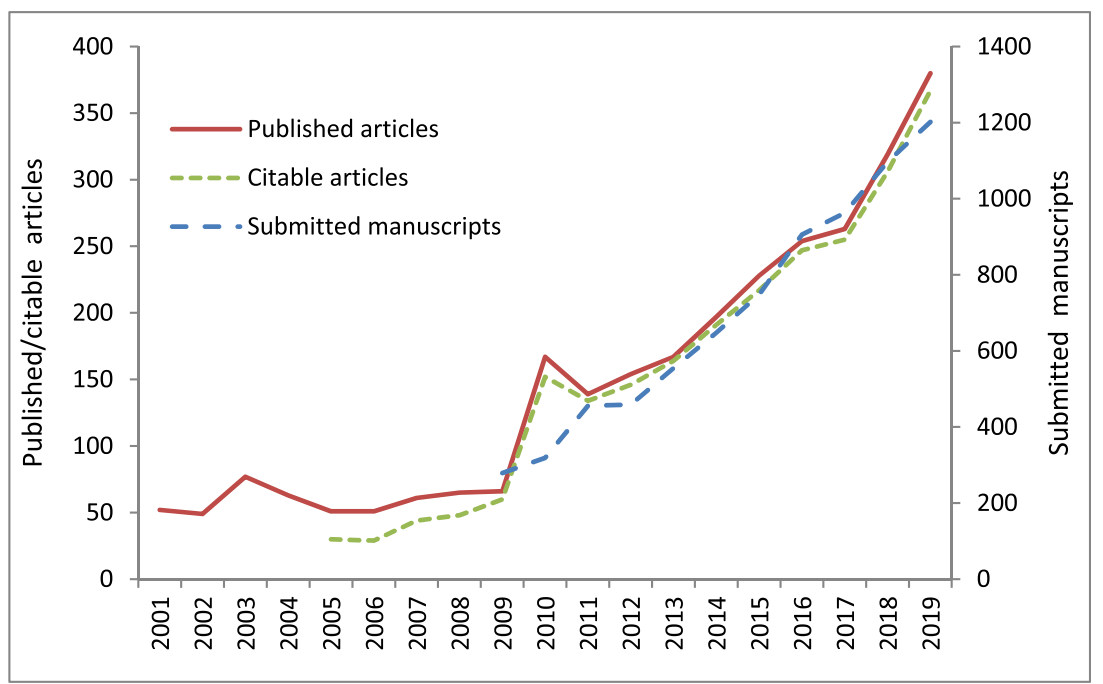

Fig. 1 Number of submitted manuscripts (2009-2019) and published (2001-2019) and citable (2005-2019) articles in Journal of Soils and Sediments. The number of citable articles is based on data from Thomson Reuters and Clarivate Analytics and is used to calculate the journal impact factor. The number of published articles includes editorials, commentaries, research reports, announcements, etc. Many

So, as JSS marks its 20th anniversary, it seems appropriate to recognize the tremendous progress that has been made and manuscripts are often re-submitted after an initial assessment, so the actual number of submitted manuscripts to be evaluated is much higher than the values illustrated. The details on the number of manuscripts submitted prior to 2009 is uncertain due to the transition in publishers but is likely to be $\sim 50$ in the early years increasing to $\sim 250$ manuscripts in 2008

also reflect on the year ahead. In terms of progress, to the EiCs and publisher, the greatest accomplishments have been the

Table 1 Top 20 papers published in JSS over the period 2009-2019 based on citations in Web of Science as of late 2019

Authors and year Title

Mench et al. (2010)

Liu et al. (2011)

Colombo et al. (2014)

Chen and Yuan (2011)

Taylor and Owens (2009)

Walling (2013)

Wang et al. (2010b)

Condron and Newman (2011)

Di et al. (2010)

Xu et al. (2012)

Wang et al. (2010a)

Hu et al. (2013)

Li et al. (2012)

Zhang et al. (2013b)

Zhang et al. (2013a)

Yuan et al. (2011)

Cui et al. (2011)

Albaladejo et al. (2013)

Bakke et al. (2010)

Guzman et al. (2013)
Successes and limitations of phytotechnologies at field scale: outcomes, assessment and outlook from COST Action 859

Reducing $\mathrm{CH}_{4}$ and $\mathrm{CO}_{2}$ emissions from waterlogged paddy soil with biochar

Review on iron availability in soil: interaction of Fe minerals, plants, and microbes

Enhanced sorption of polycyclic aromatic hydrocarbons by soil amended with biochar

Sediments in urban river basins: a review of sediment-contaminant dynamics in an environmental system conditioned by human activities

The evolution of sediment source fingerprinting investigations in fluvial systems

Sorption of the herbicide terbuthylazine in two New Zealand forest soils amended with biosolids and biochars

Revisiting the fundamentals of phosphorus fractionation of sediments and soils

Nitrous oxide emissions from grazed grassland as affected by a nitrification inhibitor, dicyandiamide, and relationships with ammonia-oxidizing bacteria and archaea

$\mathrm{pH}$ buffering capacity of acid soils from tropical and subtropical regions of China as influenced by incorporation of crop straw biochars

Heavy metal pollution of the world largest antimony mine-affected agricultural soils in Hunan province (China)

$\mathrm{pH}$-dependent distribution of soil ammonia oxidizers across a large geographical scale as revealed by high-throughput pyrosequencing

Are the biogeochemical cycles of carbon, nitrogen, sulfur, and phosphorus driven by the Fe-III-Fe-II redox wheel in dynamic redox environments?

Ecological stoichiometry of carbon, nitrogen, and phosphorus in estuarine wetland soils: influences of vegetation coverage, plant communities, geomorphology, and seawalls

Biochars immobilize soil cadmium, but do not improve growth of emergent wetland species Juncus subsecundus in cadmium-contaminated soil

Comparison of the ameliorating effects on an acidic ultisol between four crop straws and their biochars

Enhancing phosphorus availability in phosphorus-fertilized zones by reducing phosphate adsorbed on ferrihydrite using rice straw-derived biochar

Land use and climate change impacts on soil organic carbon stocks in semi-arid Spain

Development of sediment quality criteria in Norway

Sediment tracers in water erosion studies: current approaches and challenges 
increasing reputation of the journal and the number of excellent papers that have been published. While metrics can be misleading, and used inappropriately, the number of times that a paper has been cited is a useful indication of its impact within the academic community. Thus, Table 1 lists the top 20 papers published in JSS over the period 2009-2019 based on citations in Web of Science in late 2019. This list illustrates the range of topics covered as well as the themes that seem to be topical. In 2011, we published a substantive editorial (Owens and $\mathrm{Xu}$ 2011) which reflected on the first 10 years of the journal and also commented on research advances and directions in the fields of soils and sediments and it is encouraging that many of the papers listed in Table 1 address these important research needs. There are some key research themes that emerge from Table 1, which include biochars and biosolids (e.g., Wang et al. 2010b; Liu et al. 2011; Chen and Yuan 2011), gas emissions from soils (e.g., Di et al. 2010; Lui et al. 2011), sediment-nutrient/contaminant interactions (e.g., Taylor and Owens 2009; Bakke et al. 2010; Condon and Newman 2011), and sediment tracing and fingerprinting (e.g., Guzman et al. 2013; Walling 2013).

In terms of the year ahead, we are excited by the number of high-quality papers that have been accepted and published On-line First and those that are going through the review process and likely to be published. Early indications are that more manuscripts will be received and more papers published in JSS in 2020 than in previous years. There are also many excellent special issues planned for 2020 including one on a recent SedNet conference, which seems appropriate given the important role of SedNet in the early years of the journal. There are also two special issues planned on Advances in Soil Processes and Technologies and on Advances in Sediment Science and Management, which will feature invited review and cutting-edge research articles.

As we enter a new decade for the journal, and a new decade for the planet, we see that research on soils and sediments is more relevant than ever in terms of issues such as food security, water security, global climate change, and ecosystem services and functions. We encourage the research community to rise to these challenges.

Acknowledgments There are many people to whom thanks are due. We will inevitably miss some people, for which we apologize. We would like to thank all present and past members of the editorial board (including past Editors-in-Chief) and all referees. Without them, we would not have been able to review and publish so many excellent papers. Thanks are also extended to the numerous individuals at Ecomed and SpringerNature who have provided encouragement, technical support, and the freedom to allow the journal to develop. A special thanks goes to Almut Heinrich, Moira Ledger, Paul Roos, and Sher Saini. We also thank all of the authors for trusting us and the journal with their valuable research and for working with us via the review process to produce-we hope - the best version of their research. All of you have helped make this a pleasant and rewarding experience.

\section{References}

Albaladejo J, Ortiz R, Garcia-Franco N, Ruiz Navarro A, Almagro M, Garcia Pintado J, Martinez-Mena M (2013) Land use and climate change impacts on soil organic carbon stocks in semi-arid Spain. J Soils Sediments 13:265-277

Bakke T, Kallqvist T, Ruus A, Breedveld GD, Hylland K (2010) Development of sediment quality criteria in Norway. J Soils Sediments 10:172-178

Blum WEH (2002) The new association between JSS and IUSS. J Soils Sediments 2:106-107

Brils J (2001) SedNet: demand-drive, European sediment research network. J Soils Sediments 1:131

Brils J (2002) The SedNet mission. J Soils Sediments 2:2-3

Brils J, de Deckere E (2003) SedNet - an evolving network aimed at sustainable sediment management. J Soils Sediments 3:127

Chen B, Yuan M (2011) Enhanced sorption of polycyclic aromatic hydrocarbons by soil amended with biochar. J Soils Sediments 11:6271

Colombo C, Palumbo G, He J-Z, Pinton R, Cesco S (2014) Review on iron availability in soil: interaction of $\mathrm{Fe}$ minerals, plants, and microbes. J Soils Sediments 14:538-548

Condron LM, Newman S (2011) Revisiting the fundamentals of phosphorus fractionation of sediments and soils. J Soils Sediments 11: $830-840$

Cui H-J, Wang MK, Fu M-L, Ci E (2011) Enhancing phosphorus availability in phosphorus-fertilized zones by reducing phosphate adsorbed on ferrihydrite using rice straw-derived biochar. J Soils Sediments 11:1135-1141

Di HJ, Cameron KC, Sherlock RR, Shen J-P, He J-Z, Winefield CS (2010) Nitrous oxide emissions from grazed grassland as affected by a nitrification inhibitor, dicyandiamide, and relationships with ammonia-oxidizing bacteria and archaea. J Soils Sediments 10: 943-954

Förstner U (2002) Sediments and the European water framework directive. J Soils Sediments 2:54

Guzman G, Quinton JN, Nearing MA, Mabit L, Gomez JA (2013) Sediment tracers in water erosion studies: current approaches and challenges. J Soils Sediments 13:816-833

Hu H-W, Zhang L-M, Dai Y, Di H-J, He J-Z (2013) pH-dependent distribution of soil ammonia oxidizers across a large geographical scale as revealed by high-throughput pyrosequencing. J Soils Sediments 13:1439-1449

Li Y, Yu S, Strong J, Wang H (2012) Are the biogeochemical cycles of carbon, nitrogen, sulfur, and phosphorus driven by the Fe-III-Fe-II redox wheel in dynamic redox environments? J Soils Sediments 12: 683-693

Liu Y, Yang M, Wu Y, Wang H, Chen Y, Wu W (2011) Reducing $\mathrm{CH}_{4}$ and $\mathrm{CO}_{2}$ emissions from waterlogged paddy soil with biochar. $\mathrm{J}$ Soils Sediments 11:930-939

Mench M, Lepp N, Bert V, Schwitzguebel J-P, Gawronski SW, Schroeder P, Vangronsveld J (2010) Successes and limitations of phytotechnologies at field scale: outcomes, assessment and outlook from COST Action 859. J Soils Sediments 10:1039-1070

Owens PN, Xu ZH (2011) Recent advances and future directions of soils and sediments research. J Soils Sediments 11:875-888

Taylor KG, Owens PN (2009) Sediments in urban river basins: a review of sediment-contaminant dynamics in an environmental system conditioned by human activities. J Soils Sediments 9:281-303

Walling DE (2013) The evolution of sediment source fingerprinting investigations in fluvial systems. J Soils Sediments 13:1658-1675

Wang X, He M, Xie J, Xi J, Lu X (2010a) Heavy metal pollution of the world largest antimony mine-affected agricultural soils in Hunan province (China). J Soils Sediments 10:827-837 
Wang H, Lin K, Hou Z, Richardson B, Gan J (2010b) Sorption of the herbicide terbuthylazine in two New Zealand forest soils amended with biosolids and biochars. J Soils Sediments 10:283-289

$\mathrm{Xu}$ ZH, Owens PN (2010) Our thanks to the editors-in-chief: Ulrich Förstner (Sediments) and Wim Salomons (Intercompartment). J Soils Sediments 10:1435

$\mathrm{Xu}$ ZH, Owens PN (2011) Developments and direction of the Journal of Soils and Sediments: 2011 and beyond. J Soils Sediments 11:1-2

Xu R-K, Zhao A-Z, Yuan J-H, Jiang J (2012) pH buffering capacity of acid soils from tropical and subtropical regions of China as influenced by incorporation of crop straw biochars. J Soils Sediments 12: 494-502

Yuan J-H, Xu R-K, Qian W, Wang R-H (2011) Comparison of the ameliorating effects on an acidic ultisol between four crop straws and their biochars. J Soils Sediments 11:741-750
Zhang Z, Solaiman ZM, Meney K, Murphy DV, Rengel Z (2013a) Biochars immobilize soil cadmium, but do not improve growth of emergent wetland species Juncus subsecundus in cadmiumcontaminated soil. J Soils Sediments 13:140-151

Zhang Z-S, Song X-L, Lu X-G, Xue Z-S (2013b) Ecological stoichiometry of carbon, nitrogen, and phosphorus in estuarine wetland soils: influences of vegetation coverage, plant communities, geomorphology, and seawalls. J Soils Sediments 13:1043-1051

Publisher's note Springer Nature remains neutral with regard to jurisdictional claims in published maps and institutional affiliations. 